\title{
ANALYSIS OF SELECTED RELIABILITY INDICATORS OF WATER SUPPLY NETWORK
}

\author{
ANALIZA WYBRANYCH WSKAŹNIKÓW \\ NIEZAWODNOŚCI SIECI WODOCIĄGOWEJ
}

\author{
Izabela Piegdoń, Barbara Tchórzewska-Cieślak, \\ Dawid Szpak, Anna Szlachta \\ Rzeszów University of Technology. Politechnika Rzeszowska
}

\begin{abstract}
The operation of the water supply network is related to ensuring the reliability of water supply to each customer. The reliability analysis of water supply can be based on reliability indicators of renewable objects such as water pipes. These indicators take into account the characteristics of the system and its components, by function or numerical characteristics. An example of reliability analysis for main and distribution pipes was made. The average renewal time, the average working time without failure and the reliability of network operation were determined.
\end{abstract}

Keywords: water supply network, reliability, reliability indicators

Streszczenie: Eksploatacja sieci wodociagowej wiaże się $z$ zapewnieniem niezawodności dostawy wody do każdego odbiorcy. Analize niezawodności dostawy wody można wykonać bazując na wskaźnikach niezawodności obiektów odnawialnych takich jak przewody wodociagowe. Wskaźniki te uwzględniaja właściwości systemu oraz jego elementów, poprzez charakterystyke funkcyjna lub liczbowa. Przedstawiono przyktad analizy niezawodności przewodów wodociagowych magistralnych oraz rozdzielczych dla których wyznaczono m.in. średni czas odnowy, średni czas pracy bezuszkodzeniowej, jak również dokonano oceny poziomu niezawodności pracy sieci.

Stowa kluczowe: sieć wodociagowa, niezawodność, wskaźniki niezawodności 
Analysis of selected reliability indicators of water supply network

Analiza wybranych wskaźników niezawodności sieci wodociagowej

\section{ANALYSIS OF SELECTED RELIABILITY INDICATORS OF WATER SUPPLY NETWORK}

\section{Introduction}

In the theory of reliability and operation of water supply objects and devices, renewable (repairable) and non-renewable objects and devices are distinguished. In case of damage, the renewable elements are repaired or replaced with new ones. The duration of renewal of an object or device is aimed at restoring its original features and properties that affect the efficiency of the entire system $[1,3,4,6,7$, $9,12-14,18,20,22,25,27,28]$. In the process of functioning of water supply systems one can distinguish two basic reliability states: $[2,5,9,10,15,16,21,23$, 24, 26]:

- state of efficiency (work),

- state of inefficiency (failure).

Depending on the purpose and scope of the water supply reliability assessment, states can be interpreted differently. The state of efficiency is the state in which the object/device performs its tasks in a continuous and uninterrupted manner. In turn, the state of inefficiency occurs when, due to failure, the object/device interrupts its work and does not perform its assumed tasks. To assess the reliability of the water supply system, the reliability indicators are used. The indicators characterize quantitatively specific properties of given objects and devices. Some of them refer only to renewable objects and some to non-renewable objects. Choosing the right indicators for reliability analysis is not easy. It depends on the purpose and scope of the assessment, which may be more or less detailed. But above all, it depends on the type and scope of research conducted in conditions of the actual functioning of the system and its operation. The tasks of the object should be analysed and its specificity should be taken into account. Sometimes, the lack of data or their incomplete and unreliable part makes it impossible to fully assess the reliability of elements or the entire system. Bearing in mind all conditions, in the subject literature the measures characterizing certain reliability properties of water supply objects were specified $[5,9,10,22]$ :

- measures of failure-free operation characterizing the object's ability to remain efficient while performing the task. This group of indicators includes: the probability of object operation, mean time between failures, failure stream parameter, failure frequency,

- repairability measures characterizing the object's susceptibility to repairs. This group includes: the average time of renewal (inefficiency), the average repair time, the average waiting time for repair, the renewal intensity and the renewal probability,

- measures of readiness and technical performance characterizing the impact of failures and related renewals. This group includes: the readiness indicator, the indicator of downtime, the indicator of technical performance. 
- measures of effectiveness defining the degree of task completion by a given water supply object. This group includes: the efficiency indicator, the water shortage factor.

- special measures characterizing the properties of water supply objects from the point of view of the operation process or operating conditions. This group includes: the indicator of the technological efficiency of the water treatment plant, the indicator of the technological efficiency of the sewage treatment plant, the indicator of downtime in the state of efficiency.

The research of water supply reliability indicators is systematically carried out by many authors and the results of their research can be found, in, among others, literature $[5,8,11,17]$. Conducting such research is very labour-consuming and time-consuming, especially when it comes to the possibility of obtaining reliable source data on the operation of the system. Available groups of indicators give the opportunity to choose and analyse those that can be used in the most effective way to assess the reliability of the analysed water system. The main purpose of the work is to analyse the water supply network based on the selected reliability indicators. Bearing in mind the analysis of the working conditions and the operation of the water-pipe network, its specificity and its tasks, to analyse the reliability of the network operation, were used, among others, such indicators as the the renewal time, time between failures, as well as the system readiness indicator. The example of analysis was prepared separately for the mains and for the distribution pipelines.

\section{Research object and research methodology}

While assessing the reliability of the operation of the water supply network, we based on a detailed technical, functional and structural analysis of the network. When assessing the reliability of the water supply network, the network can be analysed as an integral whole or its individual components can be separated and analysed individually. The division of the network, depending on the aim of research, can be made in stages and according to various criteria. The water supply network for which the analysis of the reliability indicators has been performed supplies about 200,000 residents. The water supply network is made up of the main network made of cast iron and steel pipes with a total length of $54.9 \mathrm{~km}$ and the distribution network with a length of 586,5 km made of cast iron, steel, PE and PVC. The total length of the network with connections is $1006,6 \mathrm{~km}$ (in 2017). In the work, the structural division of the analysed water supply network was assumed as the main and the distribution pipelines. In the further stage of the research, the division was adopted in view of the material from which the network is made and the diameters of the pipes. The type of failure and network operation time were 
Analysis of selected reliability indicators of water supply network Analiza wybranych wskaźników niezawodności sieci wodociagowej

also taken into account. The source of data was the operational documentation regarding failures in the water supply network in the period from September 2012 to the end of January 2017.

The set of data contained the following information: date of failure notification, street where the failure occurred, material and diameter of the damaged pipe, cause of failure, repair time, date of failure removal, type of pipe. The received failure log did not contain information about the waiting time for repair, therefore its value was assumed to be 0 . It was assumed that the renewal time is equal to the repair time $\left(T_{0}=T_{n}\right)$. The repair time was determined in the division proposed above. After determining the repair times, the average repair time and the readiness indicator for failure free operation were determined. In order to determine the time of failure-free operation, the diagram was used as shown in Figure 1, where $T_{p}$ was assumed as the failure-free operation time, $\mathrm{T}_{\mathrm{o}}$ - time of renewal, $\mathrm{t}$ 'as the moment of failure and $\mathrm{t}^{\prime}$ 'object renewal and restoration to work.

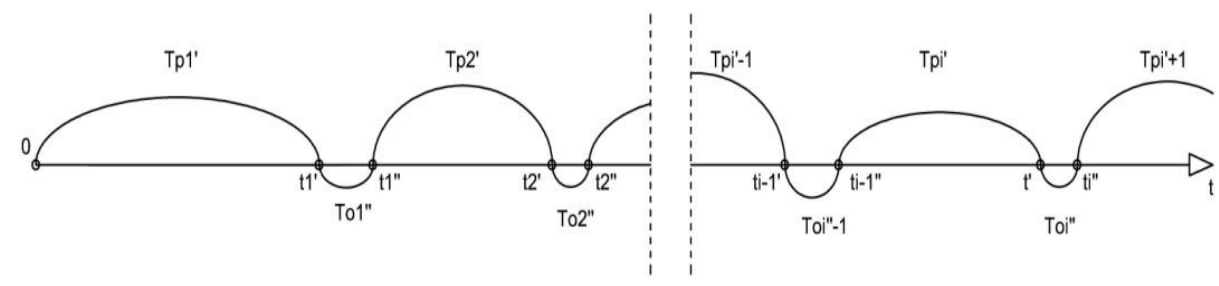

Fig.1 The renewable element exploitation process (own study based on [10])

The following indicators were used to analyze the reliability of the network:

- the renewal time To - the sum of the time of preparing repair and the real repair time

$$
T_{o}=T_{o n}+T_{n}
$$

Due to the lack of data regarding the waiting time for repair (organizing the repair), $T_{\text {on }}=0$ was assumed. This time covers the time from the moment when failure occurs to the moment when real repair starts. Therefore $T_{0}=T_{n}$ was assumed.

- repair time $\mathrm{T}_{\mathrm{n}}$ - the time from the moment when work related to the real repair of failure starts to the end of this work, i.e. the moment when water is again supply to the recipients. The values were read from the failure logs..

- the average repair time $T_{\text {nśr }}$

$$
T_{n s r}=\frac{(\text { the' sum' of 'repair' time' in' considered ' period ) }}{\text { number' of 'repairs' in' considered ' period }}
$$


- the failure-free working time $T_{p}$ - time of failure-free operation of subsystem elements between successive failures

$$
T_{p}=T_{\text {duration of the research }}-T_{n}
$$

- the mean time between failures $T_{p s ́ r}$

$$
T_{p s r}=\frac{\left(\text { time }^{\prime} \text { of ' research }\right)-T_{n}}{\text { number' of 'repairs'in' research' period }+1}
$$

- the readiness indicator $\mathrm{K}_{\mathrm{g}}$ - determines the probability that the system will be in a state of efficiency at a given time $\mathrm{t}$.

$$
K_{g}=\frac{T_{p}}{T_{p}+T_{n}}
$$

\section{The analysis of results}

The analysis of the reliability indicators was made on the basis of data from the failure logs, for the main and distribution network. The duration of the study is the period from September 4, 2012 to January 31, 2017, which gives a total of 6111 d, which, in turn, is 38.664 hours of system operation. Table 1 presents a list of the times of renewal of the main water pipes, specifying the type of failure and the

\begin{tabular}{|c|c|c|c|c|c|c|c|c|c|c|c|}
\hline \multirow{5}{*}{ 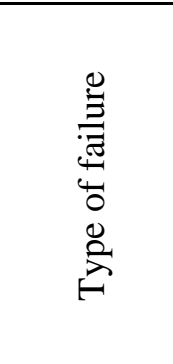 } & \multicolumn{11}{|c|}{ RENEWAL TIME, h } \\
\hline & \multicolumn{11}{|c|}{ main water pipes } \\
\hline & \multicolumn{11}{|c|}{ diameter } \\
\hline & \multicolumn{6}{|c|}{$\begin{array}{c}\mathrm{d} \leq 200 \mathrm{~mm} \\
\quad \div \\
\mathrm{d}<400 \mathrm{~mm}\end{array}$} & \multicolumn{3}{|c|}{$\begin{array}{c}\mathrm{d} \geq 400 \mathrm{~mm} \\
\div \\
\mathrm{d}<600 \mathrm{~mm}\end{array}$} & \multicolumn{2}{|c|}{$\begin{array}{c}\mathrm{d} \geq 600 \mathrm{~mm} \\
\div \\
\mathrm{d} \leq 800 \mathrm{~mm}\end{array}$} \\
\hline & $\frac{1}{2}$ & D &. & $\bar{\Phi}$ & U & W & $\frac{1}{2}$ & $\bar{\Phi}$ & W & $\underset{\bar{E}}{\tilde{\omega}}$ & W \\
\hline Crack & 0 & 8 & 16 & 0 & 0 & 24 & 0 & 0 & $\mathbf{0}$ & 0 & $\mathbf{0}$ \\
\hline Unsealing & 32 & 0 & 1194 & 0 & 8 & 1234 & 8 & 0 & 8 & 0 & $\mathbf{0}$ \\
\hline Corrosion & 0 & 0 & 72 & 242 & 0 & 314 & 0 & 236 & 236 & 39 & 39 \\
\hline Break & 0 & 0 & 40 & 0 & 0 & 40 & 0 & 0 & $\mathbf{0}$ & 0 & $\mathbf{0}$ \\
\hline $\begin{array}{l}\text { Mechanic } \\
\text { al damage }\end{array}$ & 0 & 0 & 23 & 6 & 0 & 29 & 0 & 8 & 8 & 0 & $\mathbf{0}$ \\
\hline SUM & 32 & 8 & 1345 & 248 & 8 & 1641 & 8 & 244 & 252 & 39 & 39 \\
\hline
\end{tabular}
diameter of the pipes.

Tab. 1 The list of the times of renewal for main water pipes [19]

Table 2 presents a list of the times of renewal of the distribution water pipelines, specifying the type of failure and the diameter of the pipes. 
Analysis of selected reliability indicators of water supply network Analiza wybranych wskaźników niezawodności sieci wodociagowej

Tab. 2 The list of the times of renewal for distribution water pipes [19]

\begin{tabular}{|c|c|c|c|c|c|c|c|c|c|c|c|c|c|c|c|c|}
\hline \multirow{5}{*}{ 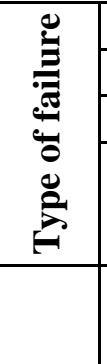 } & \multirow{2}{*}{\multicolumn{16}{|c|}{$\begin{array}{c}\text { RENEWAL TIME, } h \\
\text { distribution pipes }\end{array}$}} \\
\hline & \multirow{2}{*}{\multicolumn{16}{|c|}{$\begin{array}{c}\text { distribution pipes } \\
\text { diameter } \\
\end{array}$}} \\
\hline & & & & & & & & & & & & & & & & \\
\hline & \multicolumn{6}{|c|}{$\mathrm{d} \geq 100 \mathrm{~mm}$} & \multicolumn{6}{|c|}{$\begin{array}{l}\mathrm{d} \geq 100 \mathrm{~mm} \\
\dot{\dot{\doteqdot}} \\
\mathrm{d}<200 \mathrm{~mm}\end{array}$} & \multicolumn{4}{|c|}{$\begin{array}{c}\mathrm{d} \geq 200 \mathrm{~mm} \\
\div \\
\mathrm{d} \leq 400 \mathrm{~mm}\end{array}$} \\
\hline & $\frac{1}{2}$ & $u_{2}^{2}$ & . & $\overline{\mathbb{D}}$ & U & W & 䆓 & $\sum_{2}^{u}$ & . & $\bar{D}$ & U & W & $\frac{1}{2}$ & $\sum_{2}^{2}$ & .ొ & W \\
\hline 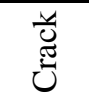 & 8 & 21 & 82 & 0 & 36 & 147 & 0 & 121 & 36 & 0 & 15 & 172 & 0 & 15 & 8 & 23 \\
\hline 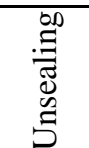 & 53 & 55 & 443 & 16 & 4 & 571 & 152 & 53 & 603 & 0 & 0 & 808 & 23 & 8 & 16 & 47 \\
\hline $\begin{array}{l}0 \\
0 \\
0 \\
0 \\
0 \\
0 \\
0\end{array}$ & 0 & 7 & 210 & 564 & 0 & 781 & 0 & 0 & 75 & 223 & 0 & 298 & 0 & 0 & 0 & O \\
\hline 岸 & 8 & 0 & 508 & 0 & 24 & 540 & 0 & 16 & 248 & 0 & 16 & 280 & 0 & 9 & 0 & 9 \\
\hline 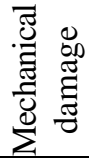 & 28 & 17 & 580 & 8 & 0 & 633 & 35 & 16 & 0 & 0 & 0 & 51 & 0 & 0 & 0 & O \\
\hline$\sum_{\text {S }}$ & 97 & 100 & 1823 & 588 & 64 & 2672 & 187 & 206 & 962 & 223 & 31 & 1609 & 23 & 32 & 24 & 79 \\
\hline
\end{tabular}

Table 3 presents a summary list of the times of renewal for the main network.

Tab. 3 A comprehensive statement of the renewal time for the water network [19]

\begin{tabular}{||l|c|c|}
\hline \multirow{2}{*}{ Type of failure } & \multicolumn{2}{|c|}{ RENEWAL TIME, $\mathbf{h}$} \\
\cline { 2 - 3 } & main network & distribution network \\
\hline Crack & 24 & 342 \\
\hline Unsealing & 1242 & 1426 \\
\hline Corrosion & 589 & 1079 \\
\hline Break & 40 & 829 \\
\hline Mechanical damage & 37 & 684 \\
\hline SUM & $\mathbf{1 9 3 2}$ & $\mathbf{4 3 6 0}$ \\
\hline
\end{tabular}


The average time of renewal for the main and distribution network was determined on the basis of formula (2). The calculated values are presented in table 4.

Tab. 4 A comprehensive statement of the average time of renewal for the water network [19]

\begin{tabular}{||l|c|c||}
\hline \multirow{2}{*}{ Type of failure } & \multicolumn{2}{|c||}{ AVERAGE TIME OF RENEWAL, $\mathbf{~}$} \\
\cline { 2 - 3 } & main network & distribution network \\
\hline Crack & 12,00 & 10,36 \\
\hline Unsealing & 16,78 & 7,47 \\
\hline Corrosion & 11,11 & 8,70 \\
\hline Break & 10,00 & 8,46 \\
\hline Mechanical damage & 2,47 & 48,86 \\
\hline SUM & 13,05 & 9,48 \\
\hline
\end{tabular}

The time of renewal consists of the waiting time for repair and the repair time. The duration of these periods depends mainly on the repair team, and more specifically on its efficiency and equipment. The time of renewal depends also on: the availability of fittings and their efficiency, location and type of failure, material and diameter of the pipes, type of ground, the depth of foundation of the pipe, type of surface. The time of repair was used to determine the average failure-free working time. Tables 5 and 6 show, respectively, the calculated failure free operation times and the average failure free working time. The formula 4 was used to calculate the average failure-free working time.

Tab. 5 A comprehensive statement of the time without failure for the water network [19]

\begin{tabular}{||l|c|c||}
\hline \multirow{2}{*}{ Type of failure } & \multicolumn{2}{|c||}{ OPERATIONAL TIME WITHOUT FAILURE, $\mathbf{h}$} \\
\cline { 2 - 3 } & main network & distribution network \\
\hline Crack & 38640 & 38322 \\
\hline Unsealing & 37422 & 37238 \\
\hline Corrosion & 38075 & 37585 \\
\hline Break & 38624 & 37835 \\
\hline Mechanical damage & 38627 & 37980 \\
\hline SUM & 191388 & 188960 \\
\hline
\end{tabular}


Analysis of selected reliability indicators of water supply network Analiza wybranych wskaźników niezawodności sieci wodociagowej

Tab. 6 A comprehensive statement of the average time without failure for the water network [19]

\begin{tabular}{||c|c|c|}
\hline \multirow{2}{*}{ Type of failure } & \multicolumn{2}{|c|}{ AVERAGE TIME WITHOUT FAILURE, $\mathbf{~}$} \\
\cline { 2 - 3 } & main network & distribution network \\
\hline Crack & 12880,00 & 1127,12 \\
\hline Unsealing & 498,96 & 193,95 \\
\hline Corrosion & 705,09 & 300,68 \\
\hline Break & 7724,80 & 382,17 \\
\hline Mechanical damage & 2414,19 & 2532,00 \\
\hline SUM & 4844,61 & 907,18 \\
\hline
\end{tabular}

In the next stage, the readiness indicator was determined, which determines the probability that the network will work at any time $t$ in the state of complete efficiency. Table 7 shows the determined values of the readiness indicator. The formula (5) was used to calculate the readiness indicator (5).

Tab. 7 Statement of values of readiness indicator for the water supply system

\begin{tabular}{||c|c||}
\hline \multicolumn{2}{|c||}{ READINESS INDICATOR- $\mathbf{K}_{\mathbf{g}}$} \\
\hline main network & $\begin{array}{c}\text { distribution } \\
\text { network }\end{array}$ \\
\hline 0,997313 & 0,989660 \\
\hline
\end{tabular}

\section{Conclusions}

The average renewal time for the main network is 13.05 hours, for the distribution network 9.48 hours. The average failure-free operation time for the main network is 4844.61 hours and for the distribution network is 907.18 hours. This value for the entire main network is $2875,895 \mathrm{~h}$. The main indicator used to determine the reliability of the water supply network is the stationary readiness indicator. The values for the main, distribution network and household connections are, respectively, 0.997313 and 0.989660 . The entire network is characterized by the size of this indicator at the level of 0.9934865 . The average renewal time affects the value of the readiness indicator. The shorter the renewal time, the higher value of the readiness indicator. The assessment of the reliability of the water supply network based on the analysis of the reliability indicators is possible when a proper complete and reliable database is available. If such data are not available, then analysis and assessment of reliability should be performed using the fuzzy logic methods. 


\section{References}

[1] Bucior J., Podstawy niezawodności, Wydawnictwo Politechniki Rzeszowskiej, Rzeszów, 1989.

[2] Budziło B., Niezawodność wybranych systemów zaopatrzenia w wode w poludniowej Polsce, Wydawnictwo Politechniki Krakowskiej, Kraków, 2010.

[3] Bukowski L. Bukowski M., Systemowa analiza ryzyka $w$ eksperckich metodach oceny niezawodności systemów, XXVIII Zimowa Szkoła Niezawodności, Wydawnictwo i Zakład Poligrafii Instytutu Technologii Eksploatacji, Szczyrk, 2000

[4] Bukowski L. Feliks J., Smalko Z., Analiza niezawodności systemów podwyższonego ryzyka, XXXV Zimowa Szkoła Niezawodności - Problemy niezawodności systemów, Szczyrk, 2007, s. 103-116.

[5] Hotloś H., Ilościowa ocena wplywu wybranych czynników na parametry $i$ koszty eksploatacyjne sieci wodociagowych, Prace Instytutu Inżynierii Ochrony Środowiska Politechniki Wrocławckiej, nr 84, Oficyna Wydawnicza Politechniki Wrocławskiej, Wrocław, 2007.

[6] Jaźwiński J. Smalko Z., Problemy decyzyjne w inżynierii niezawodności, XXVIII Zimowa Szkoła Niezawodności - Problemy decyzyjne w inżynierii niezawodności, Szczyrk, 2000

[7] Kołowrocki K. Smalko Z., Safety and reliability of a three-state system at variable operation conditions, Scientific problems of machines operation and maintenance, Komitet Budowy Maszyn PAN, 2(166)/2011, s. 47-54.

[8] Królikowska J. Królikowski A., Analiza porównawcza wskaźników niezawodności wiejskich $i$ komunalnych systemów zaopatrzenia $w$ wodę, XXI Krajowa Konferencja IX Międzynarodowa Konferencja „Zaopatrzenie w wodę, jakość i ochrona wód”, PZITS O/Wielkopolski, Poznań, 2010, t. II, s. 411-419.

[9] Kwietniewski M. Rak J., Niezawodność infrastruktury wodociagowej $i$ kanalizacyjnej w Polsce, Studia z zakresu inżynierii nr 67, Polska Akademia Nauk, Komitet Inżynierii Lądowej i Wodnej, Instytut Podstawowych Problemów Techniki, Warszawa, 2010.

[10] Kwietniewski M., Roman M., and Kłoss-Trębaczkiewicz H., Niezawodność wodociagów i kanalizacji, Arkady, 1993.

[11] Kwietniewski M. Sudoł M., Wskaźniki niezawodności dystrybucji wody o wymaganej jakości, XVIII Krajowa Konferencja VI Międzynarodowa Konferencja „Zaopatrzenie w wodę, jakość i ochrona wód”, PZITS O/Wielkopolski, Poznań, 2004, s. 581-591.

[12] Młyńczak M., Metodyka badań eksploatacyjnych obiektów mechanicznych, Oficyna Wydawnicza Politechniki Wrocławskiej Wrocław, 2012.

[13] Nowakowski T., Niezawodność systemów logistycznych, Oficyna Wydawnicza Politechniki Wrocławskiej, Wrocław, 2011. 
Analysis of selected reliability indicators of water supply network Analiza wybranych wskaźników niezawodności sieci wodociagowej

[14] Nowakowski T., Reliability model of combined transportation system, in PSAM 7 - ESREL 2004. 2004: Berlin. p. 2012-2017.

[15] Rak J., Wybrane zagadnienia niezawodności i bezpieczeństwa w zaopatrzeniu $w$ wodę, Oficyna Wydawnicza Politechniki Rzeszowskiej, Rzeszów, 2008.

[16] Rak J. Iwanejko R., Wieczysty A., Analiza wstępna badań niezawodnościowych, Gaz, Woda i Technika Sanitarna, Sigma-NOT, 12/1994.

[17] Roman M. Kłoss-Trębaczkiewicz H., Szerejko A., Wskaźniki gotowości elementów pompowni wodociagowych, Konferencja,,Niezawodność systemów wodociągowych i kanalizacyjnych", PZITS O/Kielce, Kielce, 1986, s. 239255.

[18] Siergiejszyk M. Paś J., Rosiński A.,, Issue of reliability-exploitation evaluation of electronic transport systems used in the railway environment with consideraton of electromagnetic interference, IET Intelligent Transport Systems, 10(9)/2016, s. 587-593.

[19] Szlachta A., Analiza niezawodności sieci wodociagowej w Rzeszowie Praca dyplomowa magisterska, $/ 2017$.

[20] Szopa T., Niezawodność i bezpieczeństwo, Oficyna Wydawnicza PW, 2009.

[21] Szpak D. Tchórzewska-Cieślak B., Water producers risk analysis connected with collective water supply system functioning, Dependability Engineering and Complex Systems. Advances in Intelligent Systems and Computing 470. Proceedings of the Eleventh International Conference on Dependability and Complex Systems DepCoS-RELCOMEX. June 27-July 1, 2016, Brunów, Poland., In: Zamojski W. et al. (eds.), Editor. 2016, Springer. p. 479-489.

[22] Tchórzewska-Cieślak B., Niezawodność $i$ bezpieczeństwo systemów komunalnych na przyktadzie systemu zaopatrzenia $w$ wodę, Oficyna Wydawnicza Politechniki Rzeszowskiej, Rzeszów, 2008.

[23] Tchórzewska-Cieślak B., Water supply system reliability management, Environment Protection Engineering, 2/2009, s. 29-35.

[24] Tchórzewska Cieślak B. Boryczko K., Piegdoń I.,, Possibilistic risk analysis of failure in water supply network, Proceedings of the European Safety and Reliability Conference, ESREL 2014, 2014, s. 1473-1480.

[25] Tchórzewska Cieślak B. Piegdoń I., The method of identyfication the failure risk on water supply networks, Journal of KONBiN, 1(37)/2016, s. 73-94.

[26] Wieczysty A., Niezawodność systemów wodociagowych i kanalizacyjnych, Skrypt. Wydawnictwo Politechniki Krakowskiej, Kraków, 1990.

[27] Zamojski W., Niezawodność i eksploatacja systemów, Wydawnictwo Politechniki Wrocławskiej, Wrocław, 1981.

[28] Zimoch I., Zintegrowana metoda analizy niezawodności funkcjonowania i bezpieczeństwa systemów zaopatrzenia $w$ wodę, Wydawnictwo Politechniki Śląskiej, Gliwice, 2011. 


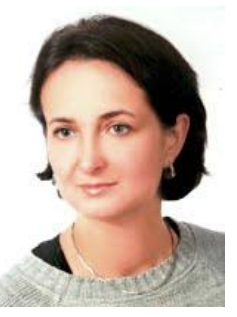

Prof. Barbara Tchórzewska-Cieślak, Ph.D.Eng. is working in the post of an associate professor in Rzeszow University of Technology, Faculty of Civil, Environmental Engineering and Architecture, Department of Water Supply and Sewage Systems. Research interests: water supply systems, reliability and safety of engineering systems, unconventional methods of risk analysis and assessment (Share 25\%).

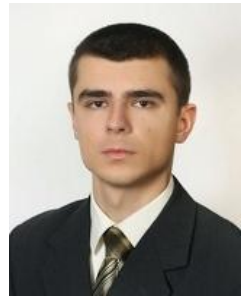

Dawid Szpak, Msc.Eng. is working in the post of an assistant in Rzeszow University of Technology, Faculty of Civil, Environmental Engineering and Architecture, Department of Water Supply and Sewage Systems. Research interests: reliability and security of water supply systems, incidental events in water supply systems (Share 25\%).

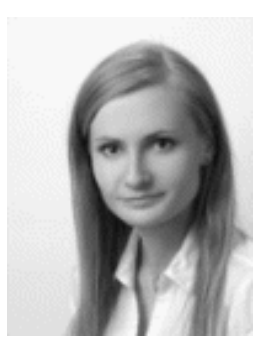

Izabela Piegdoń, Msc.Eng. is working in the post of an assistant in Rzeszow University of Technology, Faculty of Civil, Environmental Engineering and Architecture, Department of Water Supply and Sewage Systems. Research interests: reliability and security of water supply systems, IT techniques in management of water distribution systems (Share 25\%).

Anna Szlachta, Msc.Eng. is a graduate of the Rzeszow University of Technology. Field of study: environmental engineering, specialization: water supply and sewage systems (Share 25\%). 
Analysis of selected reliability indicators of water supply network

Analiza wybranych wskaźników niezawodności sieci wodociagowej

\section{ANALIZA WYBRANYCH WSKAŹNIKÓW NIEZAWODNOŚCI SIECI WODOCIĄGOWEJ}

\section{Wprowadzenie}

W teorii niezawodności oraz funkcjonowania obiektów i urządzeń wodociągowych wyróżnia się obiekty i urządzenia odnawialne (naprawialne) lub nieodnawialne. W przypadku uszkodzenia elementy odnawialne są naprawiane bądź też wymieniane na nowe. Sam czas trwania odnowy obiektu lub urządzenia ma na celu przywrócenie jego pierwotnych cech i własności, które wpływają na efektywność działania całego systemu $[1,3,4,6,7,9,12-14,18,20,22,25,27,28]$. W procesie funkcjonowania systemów wodociągowych można wyróżnić dwa podstawowe stany niezawodności $[2,5,9,10,15,16,21,23,24,26]$ :

- stan sprawności (pracy),

- stan niesprawności (uszkodzenia).

W zależności od celu i zakresu oceny niezawodności sieci wodociągowej, stany mogą być różnie interpretowane. Stan sprawności to taki stan w którym obiekt/urządzenie wykonuje swoje zadania w sposób ciągły i nieprzerywany. Z kolei stan niesprawności następuje wtedy kiedy na skutek uszkodzenia obiekt/urządzenie przerywa swoją pracę i nie wykonuje swoich założonych zadań. Do oceny niezawodności systemu wodociągowego stosuje się wskaźniki niezawodności. Wskaźniki charakteryzują ilościowo określone właściwości danych obiektów i urządzeń. Niektóre z nich odnoszą się tylko do obiektów odnawialnych a część do obiektów nieodnawialnych. Wybór odpowiednich wskaźników do analizy niezawodności nie jest prosty. Zależy od celu i zakresu oceny, która może być mniej lub bardziej szczegółowa. Lecz przede wszystkim zależy od rodzaju i zakresu badań prowadzonych w warunkach rzeczywistego funkcjonowania systemu oraz jego eksploatacji. Należy przeanalizować zadania stawiane obiektowi oraz uwzględnić jego specyfikę. Bywa, iż brak danych lub ich niepełna i niewiarygodna część uniemożliwia dokonanie pełnej oceny niezawodności elementów bądź całego systemu. Mając na uwadze wszelkie uwarunkowania, w literaturze przedmiotu wyszczególniono miary charakteryzujące określone właściwości niezawodnościowe obiektów wodociągowych [5, 9, 10, 22]:

- miary bezawaryjności charakteryzujące zdolność obiektu do zachowania sprawności podczas wykonywania zadania. Do tej grupy wskaźników zalicza się: prawdopodobieństwo pracy obiektu, średni czas pracy między uszkodzeniami, parametr strumienia uszkodzeń, częstość uszkodzeń.

- miary naprawialności charakteryzujące podatność obiektu na wykonane naprawy. Do tej grupy należą: średni czas odnowy (niesprawności), średni czas naprawy, średni czas oczekiwania na naprawę, intensywność odnowy, prawdopodobieństwo odnowy. 
- miary gotowości i technicznego wykorzystania charakteryzujące wpływ uszkodzeń i związanych z nimi odnów. Do tej grupy należą: wskaźnik gotowości, wskaźnik postoju, wskaźnik wykorzystania technicznego.

- miary efektywności określające stopień realizacji zadania przez dany obiekt wodociągowy. Do tej grupy należą: wskaźnik efektywności, współczynnik niedoboru wody.

- miary specjalne charakteryzujące własności obiektów wodociągowych z punktu widzenia procesu funkcjonowania czy warunków eksploatacji. Do tej grupy należą: wskaźnik technologicznej sprawności stacji uzdatniania wody, wskaźnik technologicznej sprawności oczyszczalni ścieków, wskaźnik postoju w stanie sprawności.

Badania wskaźników niezawodności sieci wodociągowych realizowane są systematycznie przez wielu autorów a ich wyniki badań można znaleźć między innymi $\mathrm{w}$ literaturze $[5,8,11,17]$. Prowadzenie badań tego typu jest bardzo pracochłonne oraz czasochłonne, zwłaszcza jeśli chodzi o możliwość uzyskania wiarygodnych danych źródłowych $\mathrm{z}$ eksploatacji systemu. Dostępne grupy wskaźników dają możliwość wyboru i analizy tych, które w najefektywniejszy sposób wykorzystać można do oceny niezawodności badanego systemu wodociągowego. Głównym celem pracy jest analiza sieci wodociaggowej na podstawie wybranych wskaźników niezawodnościowych. Mając na uwadze analizę warunków pracy oraz proces eksploatacji sieci wodociągowej, jej specyfikę oraz stawiane jej zadania, do analizy niezawodności pracy sieci wykorzystano m.in. wskaźniki: czasu odnowy, czasu pracy bezuszkodzeniowej jak również wskaźnik gotowości systemu. Przykład analizy został sporządzony oddzielnie dla przewodów magistralnych oraz oddzielnie dla przewód rozdzielczych.

\section{Obiekt i metodyka badań}

Podczas dokonywania oceny niezawodności funkcjonowania sieci wodociągowej bazuje się na szczegółowej analizie technicznej, funkcjonalnej oraz strukturalnej sieci. Oceniając niezawodność sieci wodociągowej można analizować ją jako integralną całość, bądź wyodrębnić i analizować jej poszczególne elementy składowe. Podział sieci w zależności od postawionego celu badań, można wykonywać etapowo i wg różnych kryteriów. Sieć wodociągowa dla której została wykonana analiza wskaźników niezawodności zaopatruje ok 200 tys. mieszkańców. Sieć wodociągową tworzy sieć magistralna wykonana z przewodów żeliwnych i stalowych o łącznej długości $54,9 \mathrm{~km}$ oraz sieć rozdzielcza o długości $586,5 \mathrm{~km}$ wykonana $\mathrm{z}$ żeliwa, stali, PE i PCV. Łączna długość sieci wraz z przyłączami wynosi $1006,6 \mathrm{~km}$ (stan na rok 2017). W pracy przyjęto podział strukturalny badanej sieci wodociągowej jako przewody magistralne oraz rozdzielcze. W dalszym etapie badań przyjęto podział ze względu na materiał z jakiego wykonana jest sieć oraz średnice przewodów. Uwzględniono również rodzaj uszkodzenia oraz czas eksploatacji sieci. 
Analysis of selected reliability indicators of water supply network Analiza wybranych wskaźników niezawodności sieci wodociagowej

Źródłem danych była dokumentacja eksploatacyjna dotycząca awarii na sieci wodociągowej w okresie od września 2012 do końca stycznia 2017r. Zbiór danych zawierał następujące informacje: data zgłoszenia awarii, ulica na której doszło do awarii, materiał i średnica uszkodzonego przewodu, przyczyna awarii, czas naprawy, data usunięcia awarii, rodzaj przewodu. Otrzymany dziennik awarii nie zawierał informacji odnośnie czasu oczekiwania na naprawę, dlatego jego wartość przyjęto na poziomie 0. Przyjęto zatem, że czas odnowy jest równy czasowi naprawy $\left(\mathrm{T}_{\mathrm{o}}=\mathrm{T}_{\mathrm{n}}\right)$. Czas naprawy wyznaczono $\mathrm{w}$ podziale zaproponowanym jak wyżej. Po wyznaczeniu czasów napraw określono średni czas naprawy oraz wskaźnik gotowości do pracy bezuszkodzeniowej. W celu wyznaczenia czasu pracy bezuszkodzeniowej wykorzystano schemat zgodnie $\mathrm{z}$ rysunkiem 1 , gdzie przyjęto Tp jako czas pracy bezuszkodzeniowej, To czas odnowy, t' jako moment uszkodzenia obiektu oraz t' odnowa obiektu i przywrócenie do pracy.

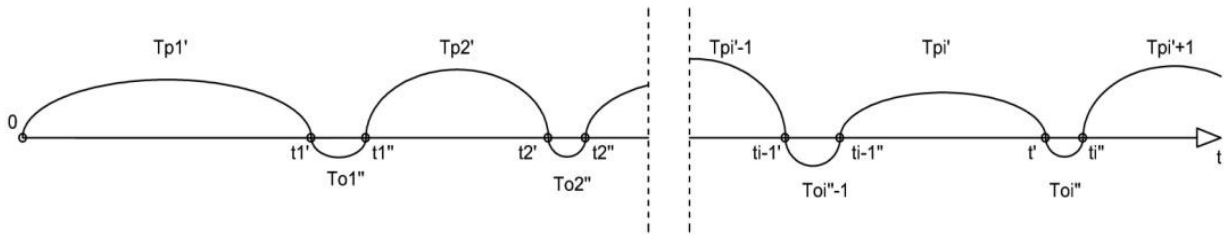

Rys. 1 Proces eksploatacji elementu odnawialnego (opracowanie wlasne na podstawie [10])

Do analizy niezawodności sieci wykorzystano następujące wskaźniki:

- czas odnowy $\mathrm{T}_{\mathrm{o}}$ - suma czasów organizacji naprawy oraz właściwej naprawy

$$
T_{o}=T_{o n}+T_{n}
$$

Ze względu na brak danych odnośnie czasu oczekiwania na naprawę (organizacji naprawy), przyjęto wartość czasu $\mathrm{T}_{\text {on }}=0$. Czas ten obejmuje czas od momentu powstania uszkodzenia do momentu przystąpienia do właściwej naprawy. Przyjęto zatem, że $T_{\mathrm{o}}=\mathrm{T}_{\mathrm{n}}$.

- czas naprawy $T_{n}$ - czas od chwili rozpoczęcia prac związanych $\mathrm{z}$ właściwą naprawą uszkodzenia do jej zakończenia, czyli do wznowienia odstawy wody do odbiorcy. Wartości $\mathrm{T}_{\mathrm{n}}$ sczytano $\mathrm{z}$ dzienników awarii.

- średni czas naprawy $\mathrm{T}_{\text {nśr }}$

$$
T_{n s r}=\frac{\left(\text { czas' }{ }^{\prime} \text { rwania' } w \text { szystkich'napraw' } w^{\prime} \text { badanym'okresie }\right)}{\text { liczba'napraw' } w^{\prime} \text { 'badanym' okresie }}
$$

- czas pracy bezuszkodzeniowej $\mathrm{T}_{\mathrm{p}}$ - czas pracy bezawaryjnej elementów podsystemu między kolejnymi uszkodzeniami.

$$
T_{p}=T_{\text {trwaniabadania }}-T_{n}
$$


- średni czas pracy bezuszkodzeniowej $\mathrm{T}_{\mathrm{pśr}}$

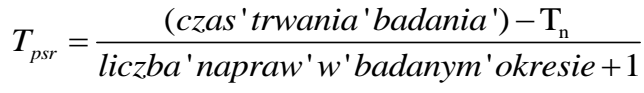

- wskaźnik gotowości $\mathrm{K}_{\mathrm{g}}$ - określa prawdopodobieństwo, że system będzie $\mathrm{w}$ stanie sprawności w danym czasie $\mathrm{t}$.

$$
K_{g}=\frac{T_{p}}{T_{p}+T_{n}}
$$

\section{Analiza wyników badań}

Analizę wskaźników niezawodności sporządzono w oparciu o dane z dzienników awarii, dla sieci magistralnej oraz rozdzielczej. Czas trwania badania stanowi okres od 4 września 2012 roku do 31 stycznia 2017, co daje łącznie 6111d, a to z kolei wynosi $38664 \mathrm{~h}$ pracy systemu. W tabeli 1 przedstawiono zestawienie czasów trwania odnowy przewodów wodociągowych magistralnych, z wyszczególnieniem rodzaju uszkodzenia oraz średnicy przewodów.

\begin{tabular}{|c|c|c|c|c|c|c|c|c|c|c|c|}
\hline \multirow{5}{*}{ 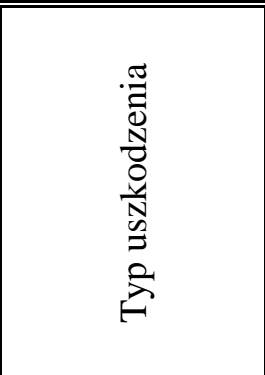 } & \multicolumn{11}{|c|}{ CZAS ODNOWY, h } \\
\hline & \multicolumn{11}{|c|}{ sieć magistralna } \\
\hline & \multicolumn{11}{|c|}{ średnica } \\
\hline & \multicolumn{6}{|c|}{$\begin{array}{c}\mathrm{d} \leq 200 \mathrm{~mm} \\
\div \quad \div \\
\mathrm{d}<400 \mathrm{~mm}\end{array}$} & \multicolumn{3}{|c|}{$\begin{array}{c}\mathrm{d} \geq 400 \mathrm{~mm} \\
\dot{\div} \\
\mathrm{d}<600 \mathrm{~mm}\end{array}$} & \multicolumn{2}{|c|}{$\begin{array}{c}\mathrm{d} \geq 600 \mathrm{~mm} \\
\div \\
\mathrm{d} \leq 800 \mathrm{~mm}\end{array}$} \\
\hline & $\frac{1}{2}$ & $\sum_{2}^{u}$ & 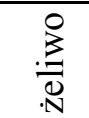 & 胥 & $\frac{U}{\varangle}$ & W & $\frac{1}{2}$ & 苛 & W & 吾 & W \\
\hline Pęknięcie & 0 & 8 & 16 & 0 & 0 & 24 & 0 & 0 & $\mathbf{0}$ & 0 & $\mathbf{0}$ \\
\hline Rozszczelnienie & 32 & 0 & 1194 & 0 & 8 & 1234 & 8 & 0 & 8 & 0 & 0 \\
\hline Korozja & 0 & 0 & 72 & 242 & 0 & 314 & 0 & 236 & 236 & 39 & 39 \\
\hline Złamanie & 0 & 0 & 40 & 0 & 0 & 40 & 0 & 0 & $\mathbf{0}$ & 0 & $\mathbf{0}$ \\
\hline $\begin{array}{l}\text { Uszkodzenia } \\
\text { mechaniczne }\end{array}$ & 0 & 0 & 23 & 6 & 0 & 29 & 0 & 8 & 8 & 0 & $\mathbf{0}$ \\
\hline SUMA & 32 & 8 & 1345 & 248 & 8 & 1641 & 8 & 244 & 252 & 39 & 39 \\
\hline
\end{tabular}

Tab. 1 Zestawienie calkowitego czasu odnowy dla sieci magistralnej [19] 
Analysis of selected reliability indicators of water supply network Analiza wybranych wskaźników niezawodności sieci wodociagowej

W tabeli 2 przedstawiono zestawienie czasów trwania odnowy przewodów wodociągowych rozdzielczych, z wyszczególnieniem rodzaju uszkodzenia oraz średnicy przewodów.

Tab. 2 Zestawienie catkowitego czasu odnowy dla sieci rozdzielczej [19]

\begin{tabular}{|c|c|c|c|c|c|c|c|c|c|c|c|c|c|c|c|c|}
\hline \multirow{5}{*}{ 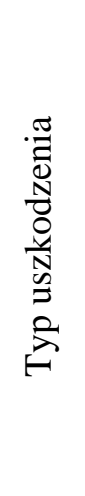 } & \multicolumn{16}{|c|}{ CZAS ODNOWY h } \\
\hline & \multicolumn{16}{|c|}{ sieć rozdzielcza } \\
\hline & \multicolumn{16}{|c|}{ średnica } \\
\hline & \multicolumn{6}{|c|}{$\mathrm{d} \geq 100 \mathrm{~mm}$} & \multicolumn{6}{|c|}{$\mathrm{d} \geq 100 \mathrm{~mm} \div \mathrm{d}<200 \mathrm{~mm}$} & \multicolumn{4}{|c|}{$\begin{array}{c}\mathrm{d} \geq 200 \mathrm{~mm} \\
\div \\
\mathrm{d} \leq 400 \mathrm{~mm}\end{array}$} \\
\hline & $\frac{1}{2}$ & U & 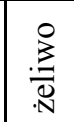 & $\bar{\Xi}$ & U & 山 & $\frac{\sqrt{2}}{2}$ & $\stackrel{u}{a}$ & 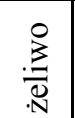 & $\frac{\pi}{6}$ & $\underset{\varangle}{U}$ & 山 & 至 & U & 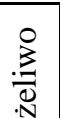 & W \\
\hline 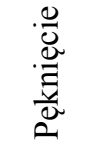 & 8 & 21 & 82 & 0 & 36 & 147 & 0 & 121 & 36 & 0 & 15 & 172 & 0 & 15 & 8 & 23 \\
\hline 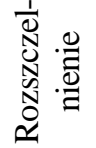 & 53 & 55 & 443 & 16 & 4 & 571 & 152 & 53 & 603 & 0 & 0 & 808 & 23 & 8 & 16 & 47 \\
\hline 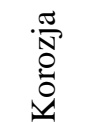 & 0 & 7 & 210 & 564 & 0 & 781 & 0 & 0 & 75 & 223 & 0 & 298 & 0 & 0 & 0 & $\mathbf{0}$ \\
\hline 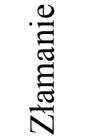 & 8 & 0 & 508 & 0 & 24 & 540 & 0 & 16 & 248 & 0 & 16 & 280 & 0 & 9 & 0 & 9 \\
\hline 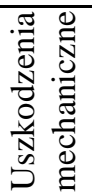 & 28 & 17 & 580 & 8 & 0 & 633 & 35 & 16 & 0 & 0 & 0 & 51 & 0 & 0 & 0 & $\mathbf{0}$ \\
\hline 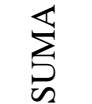 & 97 & 100 & 1823 & 588 & 64 & 2672 & 187 & 206 & 962 & 223 & 31 & 1609 & 23 & 32 & 24 & 79 \\
\hline
\end{tabular}


W tabeli 3 przedstawiono zbiorcze zestawienie wartości czasu odnowy dla sieci magistralnej.

Tab. 3 Calościowe zestawienie czasu odnowy dla sieci wodociagowej [19]

\begin{tabular}{||l|c|c||}
\hline \multirow{2}{*}{ Typ uszkodzenia } & \multicolumn{2}{|c|}{ CZAS ODNOWY, h } \\
\cline { 2 - 3 } & sieć magistralna & \multirow{2}{*}{ sieć rozdzielcza } \\
\hline Pęknięcie & 24 & 342 \\
\hline Rozszczelnienie & 1242 & 1426 \\
\hline Korozja & 589 & 1079 \\
\hline Złamanie & 40 & 829 \\
\hline Uszkodzenia mechaniczne & 37 & 684 \\
\hline SUMA & $\mathbf{1 9 3 2}$ & $\mathbf{4 3 6 0}$ \\
\hline
\end{tabular}

Średni czas odnowy dla sieci magistralnej i rozdzielczej wyznaczono na podstawie wzoru (2). Obliczone wartości przedstawiono w tabeli 4.

Tab.4 Calościowe zestawienie wartości średniego czasu odnowy dla sieci wodociagowej [19]

\begin{tabular}{||l|c|c||}
\hline \multirow{2}{*}{ Typ uszkodzenia } & \multicolumn{2}{|c|}{ ŚREDNI CZAS ODNOWY, h } \\
\cline { 2 - 3 } & sieć magistralna & sieć rozdzielcza \\
\hline Pęknięcie & 12,00 & 10,36 \\
\hline Rozszczelnienie & 16,78 & 7,47 \\
\hline Korozja & 11,11 & 8,70 \\
\hline Złamanie & 10,00 & 8,46 \\
\hline $\begin{array}{l}\text { Inne uszkodzenia } \\
\text { mechaniczne }\end{array}$ & 2,47 & 48,86 \\
\hline SUMA & 13,05 & 9,48 \\
\hline
\end{tabular}

$\mathrm{Na}$ czas odnowy składa się czas oczekiwania na naprawę oraz czas naprawy. Długość trwania tych okresów w głównej mierze zależy od zespołu dokonującego napraw, a dokładniej od jego sprawności i wyposażenia. Czas odnowy zależny jest również od: dostępności uzbrojenia i jego sprawności, lokalizacji i rodzaju uszkodzenia, materiału i średnicy przewodu, rodzaju gruntu, głębokości posadowienia przewodu, rodzaju nawierzchni. Do wyznaczenia średniego czasu pracy bezuszkodzeniowej posłużono się danymi czasu naprawy. 
Analysis of selected reliability indicators of water supply network Analiza wybranych wskaźników niezawodności sieci wodociagowej

Tabele 5 i 6 przedstawiają kolejno obliczone czasy pracy bezuszkodzeniowej oraz średni czas pracy bezuszkodzeniowej. Do obliczenia średniego czasu pracy bezuszkodzeniowej posłużono się wzorem 4 .

Tab. 5 Zestawienie wartości czasu pracy bezuszkodzeniowej dla sieci wodociagowej [19]

\begin{tabular}{||l|c|c||}
\hline \multirow{2}{*}{ Typ uszkodzenia } & \multicolumn{2}{|c||}{ CZAS PRACY BEZUSZKODZENIOWEJ, h } \\
\cline { 2 - 3 } & sieć magistralna & sieć rozdzielcza \\
\hline Pęknięcie & 38640 & 38322 \\
\hline Rozszczelnienie & 37422 & 37238 \\
\hline Korozja & 38075 & 37585 \\
\hline Złamanie & 38624 & 37835 \\
\hline $\begin{array}{l}\text { Inne uszkodzenia } \\
\text { mechaniczne }\end{array}$ & 38627 & 37980 \\
\hline SUMA & 191388 & 188960 \\
\hline
\end{tabular}

Tab. 6 Zestawienie wartości średniego czasu pracy bezuszkodzeniowej dla sieci wodociagowej [19]

\begin{tabular}{||l|c|c||}
\hline \multirow{2}{*}{ Typ uszkodzenia } & \multicolumn{2}{|c|}{$\begin{array}{c}\text { ŚREDNI CZAS PRACY } \\
\text { BEZUSZKODZENIOWEJ, h }\end{array}$} \\
\cline { 2 - 3 } & sieć magistralna & sieć rozdzielcza \\
\hline Pęknięcie & 12880,00 & 1127,12 \\
\hline Rozszczelnienie & 498,96 & 193,95 \\
\hline Korozja & 705,09 & 300,68 \\
\hline Złamanie & 7724,80 & 382,17 \\
\hline $\begin{array}{l}\text { Inne uszkodzenia } \\
\text { mechaniczne }\end{array}$ & 2414,19 & 2532,00 \\
\hline Średnia & 4844,61 & 907,18 \\
\hline
\end{tabular}

W kolejnym etapie wyznaczono wskaźnik gotowości, który określa prawdopodobieństwo tego, że sieć będzie pracować w dowolnej chwili t w stanie całkowitej zdatności. Tabela 7 przedstawia wyznaczone wartości wskaźnika gotowości. Do obliczenia wskaźnika gotowości posłużono się wzorem (5).

Tab. 7 Zestawienie wartości wskaźnika gotowości dla sieci wodociagowej

\begin{tabular}{||l|l||}
\hline \multicolumn{2}{|l||}{ WSKAŹNIK GOTOWOŚCI - Kg } \\
\hline sieć magistralna & sieć rozdzielcza \\
\hline 0,997313 & 0,989660 \\
\hline
\end{tabular}




\section{Wnioski}

Średni czas odnowy dla sieci magistralnej wynosi $13,05 \mathrm{~h}$, dla rozdzielczej 9,48 h. Średni czas pracy bezuszkodzeniowej dla sieci magistralnej wynosi 4844,61 h zaś dla rozdzielczej $907,18 \mathrm{~h}$. Wartość ta dla całej sieci magistralnej wynosi 2875,895 h. Głównym wskaźnikiem używanym do określania niezawodności sieci wodociągowej jest stacjonarny wskaźnik gotowości. Wartości te dla magistrali, sieci rozdzielczej oraz przyłączy wynoszą odpowiednio: 0,997313 i 0,989660. Cała sieć charakteryzuje się wielkością tego wskaźnika na poziomie 0,9934865 . Na wartość wskaźnika gotowości przewodu ma wpływ średni czas odnowy. Im krótszy czas odnowy, tym ww. wskaźnik wykazuje większą wartość. Dokonanie oceny niezawodności sieci wodociągowej na podstawie analizy wskaźników niezawodności jest możliwe wtedy, gdy dysponuje się odpowiednio pełną i rzetelną bazą danych. Jeżeli brak jest takich danych, wówczas analizę i ocenę niezawodności należy wykonać posługując się metodami logiki rozmytej.

\section{Bibliografia}

[1] Bucior J., Podstawy niezawodności, Wydawnictwo Politechniki Rzeszowskiej, Rzeszów, 1989.

[2] Budziło B., Niezawodność wybranych systemów zaopatrzenia w wode w południowej Polsce, Wydawnictwo Politechniki Krakowskiej, Kraków, 2010.

[3] Bukowski L. Bukowski M., Systemowa analiza ryzyka w eksperckich metodach oceny niezawodności systemów, XXVIII Zimowa Szkoła Niezawodności, Wydawnictwo i Zakład Poligrafii Instytutu Technologii Eksploatacji, Szczyrk, 2000

[4] Bukowski L. Feliks J., Smalko Z., Analiza niezawodności systemów podwyższonego ryzyka, XXXV Zimowa Szkoła Niezawodności - Problemy niezawodności systemów, Szczyrk, 2007, s. 103-116.

[5] Hotloś H., Ilościowa ocena wpływu wybranych czynników na parametry i koszty eksploatacyjne sieci wodociagowych, Prace Instytutu Inżynierii Ochrony Środowiska Politechniki Wrocławckiej, nr 84, Oficyna Wydawnicza Politechniki Wrocławskiej, Wrocław, 2007.

[6] Jaźwiński J. Smalko Z., Problemy decyzyjne w inżynierii niezawodności, XXVIII Zimowa Szkoła Niezawodności - Problemy decyzyjne w inżynierii niezawodności, Szczyrk, 2000

[7] Kołowrocki K. Smalko Z., Safety and reliability of a three-state system at variable operation conditions, Scientific problems of machines operation and maintenance, Komitet Budowy Maszyn PAN, 2(166)/2011, s. 47-54.

[8] Królikowska J. Królikowski A., Analiza porównawcza wskaźników niezawodności wiejskich i komunalnych systemów zaopatrzenia $w$ wodę, XXI Krajowa Konferencja IX Międzynarodowa Konferencja „Zaopatrzenie w wodę, jakość i ochrona wód”, PZITS O/Wielkopolski, Poznań, 2010, t. II, s. 411-419. 
Analysis of selected reliability indicators of water supply network Analiza wybranych wskaźników niezawodności sieci wodociagowej

[9] Kwietniewski M. Rak J., Niezawodność infrastruktury wodociagowej $i$ kanalizacyjnej $w$ Polsce, Studia z zakresu inżynierii nr 67, Polska Akademia Nauk, Komitet Inżynierii Lądowej i Wodnej, Instytut Podstawowych Problemów Techniki, Warszawa, 2010.

[10] Kwietniewski M., Roman M., and Kłoss-Trębaczkiewicz H., Niezawodność wodociagów i kanalizacji, Arkady, 1993.

[11] Kwietniewski M. Sudoł M., Wskaźniki niezawodności dystrybucji wody o wymaganej jakości, XVIII Krajowa Konferencja VI Międzynarodowa Konferencja „Zaopatrzenie w wodę, jakość i ochrona wód”, PZITS O/Wielkopolski, Poznań, 2004, s. 581- 591.

[12] Młyńczak M., Metodyka badań eksploatacyjnych obiektów mechanicznych, Oficyna Wydawnicza Politechniki Wrocławskiej Wrocław, 2012.

[13] Nowakowski T., Niezawodność systemów logistycznych, Oficyna Wydawnicza Politechniki Wrocławskiej, Wrocław, 2011.

[14] Nowakowski T., Reliability model of combined transportation system, in PSAM 7 - ESREL 2004. 2004: Berlin. p. 2012-2017.

[15] Rak J., Wybrane zagadnienia niezawodności i bezpieczeństwa w zaopatrzeniu $w$ wodę, Oficyna Wydawnicza Politechniki Rzeszowskiej, Rzeszów, 2008.

[16] Rak J. Iwanejko R., Wieczysty A., Analiza wstępna badań niezawodnościowych, Gaz, Woda i Technika Sanitarna, Sigma-NOT, 12/1994.

[17] Roman M. Kłoss-Trębaczkiewicz H., Szerejko A., Wskaźniki gotowości elementów pompowni wodociagowych, Konferencja,,Niezawodność systemów wodociągowych i kanalizacyjnych”, PZITS O/Kielce, Kielce, 1986, s. 239255.

[18] Siergiejszyk M. Paś J., Rosiński A.,, Issue of reliability-exploitation evaluation of electronic transport systems used in the railway environment with consideraton of electromagnetic interference, IET Intelligent Transport Systems, 10(9)/2016, s. 587-593.

[19] Szlachta A., Analiza niezawodności sieci wodociagowej w Rzeszowie Praca dyplomowa magisterska, $/ 2017$.

[20] Szopa T., Niezawodność i bezpieczeństwo, Oficyna Wydawnicza PW, 2009.

[21] Szpak D. Tchórzewska-Cieślak B., Water producers risk analysis connected with collective water supply system functioning, Dependability Engineering and Complex Systems. Advances in Intelligent Systems and Computing 470. Proceedings of the Eleventh International Conference on Dependability and Complex Systems DepCoS-RELCOMEX. June 27-July 1, 2016, Brunów, Poland., In: Zamojski W. et al. (eds.), Editor. 2016, Springer. p. 479-489.

[22] Tchórzewska-Cieślak B., Niezawodność $i$ bezpieczeństwo systemów komunalnych na przykładzie systemu zaopatrzenia $w$ wodę, Oficyna Wydawnicza Politechniki Rzeszowskiej, Rzeszów, 2008.

[23] Tchórzewska-Cieślak B., Water supply system reliability management, Environment Protection Engineering, 2/2009, s. 29-35. 
[24] Tchórzewska Cieślak B. Boryczko K., Piegdoń I.,, Possibilistic risk analysis of failure in water supply network, Proceedings of the European Safety and Reliability Conference, ESREL 2014, 2014, s. 1473-1480.

[25] Tchórzewska Cieślak B. Piegdoń I., The method of identyfication the failure risk on water supply networks, Journal of KONBiN, 1(37)/2016, s. 73-94.

[26] Wieczysty A., Niezawodność systemów wodociagowych $i$ kanalizacyjnych, Skrypt. Wydawnictwo Politechniki Krakowskiej, Kraków, 1990.

[27] Zamojski W., Niezawodność i eksploatacja systemów, Wydawnictwo Politechniki Wrocławskiej, Wrocław, 1981.

[28] Zimoch I., Zintegrowana metoda analizy niezawodności funkcjonowania i bezpieczeństwa systemów zaopatrzenia $w$ wodę, Wydawnictwo Politechniki Śląskiej, Gliwice, 2011.

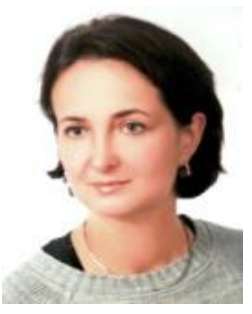

Dr hab. inż. Barbara Tchórzewska-Cieślak, prof. PRz pracuje na stanowisku profesora nadzwyczajnego $w$ Politechnice Rzeszowskiej w Katedrze Zaopatrzenia w Wodę i Odprowadzania Ścieków.Zainteresowania naukowe - eksploatacja systemów zbiorowego zaopatrzenia $w$ wodę, niezawodność i bezpieczeństwo systemów inżynierskich, niekonwencjonalne metody analizy i oceny ryzyka (Udziat 25\%).

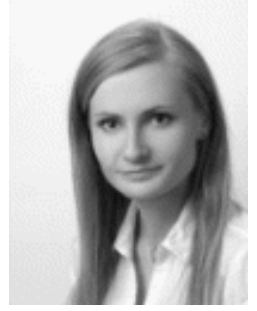

Mgr inż. Izabela Piegdoń pracuje na stanowisku asystenta $w$ Politechnice Rzeszowskiej w Katedrze Zaopatrzenia w Wode $i$ Odprowadzania Ścieków. Zainteresowania naukowe niezawodność i bezpieczeństwo systemów inżynierskich, techniki informatyczne w zarzadzaniu systemami dystrybucji wody (Udziat $25 \%)$.

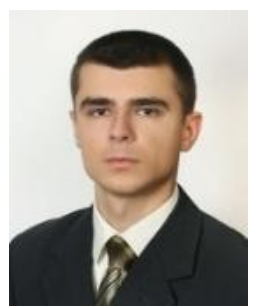

Mgr in.. Dawid Szpak pracuje na stanowisku asystenta w Zaktadzie Zaopatrzenia w Wodę i Odprowadzania Ścieków Politechniki Rzeszowskiej. Zainteresowania naukowe: niezawodność $i$ bezpieczeństwo systemów zaopatrzenia $w$ wodę, zdarzenia incydentalne $w$ systemach zaopatrzenia $w$ wode (Udziat 25\%).

Mgr inz. Anna Szlachta. W 2017 roku obronita tytut magistra inżynieria na Wydziale Budownictwa, Inżynierii Środowiska i Architektury, na kierunku Inżynieria Środowiska, specjalizacja zaopatrzenie $w$ wode $i$ odprowadzanie ścieków (Udział 25\%). 